\title{
Association of the medical therapy with beta-blockers or inhibitors of renin- angiotensin system with clinical outcomes in patients with mildly reduced left ventricular ejection fraction after acute myocardial infarction
}

\section{Short title: Medical therapy for mildly reduced EF after AMI}

Seung-Jae Joo ${ }^{1,3}$, Song-Yi Kim ${ }^{1,3}$, Jae-Geun Lee, ${ }^{1,3}$, Joon-Hyouk Choi ${ }^{1,3}$, Hyeung Keun Park², Jong Wook Beom³ ${ }^{3}$ Ki Yung Boo ${ }^{3}$, Chang-Hwan Yoon ${ }^{4}$, Jung-Hee Lee ${ }^{5}$, Seung-Ho Hur ${ }^{6}$, Jei $\mathrm{Keon}_{\mathrm{Chae}}{ }^{7}$, Myung Ho Jeong ${ }^{8}$; on behalf of the KAMIR-NIH registry investigators

${ }^{1}$ Department of Internal Medicine, Jeju National University College of Medicine, Jeju, Republic of Korea

${ }^{2}$ Department of Health Policy and Management, Jeju National University College of Medicine, Jeju, Republic of Korea

${ }^{3}$ Department of Internal Medicine, Jeju National University Hospital, Jeju, Republic of Korea ${ }^{4}$ Cardiovascular Center, Seoul National University Bundang Hospital, Seongnam, Republic of Korea

${ }^{5}$ Division of Cardiology, Yeungnam University Medical Center, Yeungnam University College of Medicine, Daegu, Republic of Korea

${ }^{6}$ Keimyung University Dongsan Medical Center, Cardiovascular Medicine, Daegu, Republic of Korea

${ }^{7}$ Department of Internal Medicine, Chonbuk National University Medical School, Jeonju, Republic of Korea 
medRxiv preprint doi: https://doi.org/10.1101/2022.03.01.22271686; this version posted March 2, 2022. The copyright holder for this preprint (which was not certified by peer review) is the author/funder, who has granted medRxiv a license to display the preprint in perpetuity.

It is made available under a CC-BY 4.0 International license.

${ }^{8}$ Department of Internal Medicine, Chonnam National University Hospital, Gwangju, Republic of Korea

Corresponding author

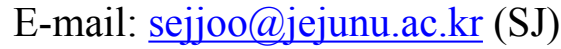


medRxiv preprint doi: https://doi.org/10.1101/2022.03.01.22271686; this version posted March 2, 2022. The copyright holder for this preprint (which was not certified by peer review) is the author/funder, who has granted medRxiv a license to display the preprint in perpetuity.

It is made available under a CC-BY 4.0 International license.

\section{Abstract}

In the era of the initial optimal interventional and medical therapy for acute myocardial infarction (AMI), a number of patients with mildly reduced left ventricular ejection fraction (EF) (41 - 49\%) have been increasing. This observational study aimed to investigate the association between the medical therapy with oral beta-blockers or inhibitors of renin-angiotensin system (RAS) and 2-year clinical outcomes in patients with mildly reduced EF after AMI. Among patients enrolled in the Korea Acute Myocardial Infarction Registry-National Institute of Health, propensity-score matched patients who survived the initial attack and had mildly reduced EF were selected according to beta-blocker or RAS inhibitor therapy at discharge. Beta-blocker therapy at discharge was associated with lower 2-year major adverse cardiac events which was a composite of cardiac death, myocardial infarction, revascularization and re-hospitalization due to heart failure (8.7 vs. 12.8/100 patient-years; hazard ratio [HR] $0.68 ; 95 \%$ confidence interval [CI] $0.50-0.93 ; P=0.015$ ), and no significant interaction between $\mathrm{EF} \leq 45 \%$ and $>45 \%$ was observed $\left(P_{\text {interaction }}=0.354\right)$. This association was mainly driven by lower myocardial infarction in patients with beta-blockers (HR 0.50; 95\% CI 0.26-0.95; $P=0.035$ ). Inhibitors of RAS at discharge were associated with lower re-hospitalization due to heart failure (1.8 vs. 3.5/100 patient-years; HR $0.53 ; 95 \% \mathrm{CI} 0.33-0.86 ; P=0.010$ ) without a significant interaction between $\mathrm{EF} \leq 45 \%$ and $>45 \%$ $\left(P_{\text {interaction }}=0.333\right)$. In patients with mildly reduced EF after AMI, the medical therapy with betablockers or RAS inhibitors at discharge was associated with better 2-year clinical outcomes. 
medRxiv preprint doi: https://doi.org/10.1101/2022.03.01.22271686; this version posted March 2, 2022. The copyright holder for this preprint (which was not certified by peer review) is the author/funder, who has granted medRxiv a license to display the preprint in perpetuity.

It is made available under a CC-BY 4.0 International license.

\section{Introduction}

Heart failure (HF) had long been classified as HF with reduced ejection fraction (HFrEF) or HF with preserved EF (HFpEF). In most clinical trials, HFrEF was defined as EF less than 35-40\%, and patients with EF above 40\% were considered to have HFpEF. However, the 2016 European Society of Cardiology (ESC) guidelines for HF suggested an intermediate phenotype, i.e. HF with mid-range EF (EF between $40 \%$ to $49 \%$ ) [1], and the 2021 ESC guidelines renamed it to HF with mildly reduced EF (HFmrEF) because retrospective analysis of clinical trials that included patients with EF in the $40-50 \%$ range showed some benefits from similar therapies to those with HFrEF [2].

An optimal medical therapy as well as early coronary reperfusion therapy is recommended in patients with acute myocardial infarction (AMI) to reduce cardiovascular mortality and morbidity. The evidence of clinical benefits of beta-blockers or inhibitors of renin-angiotensin system (RAS) after AMI is based on the clinical trials which enrolled patients with left ventricular (LV) EF below 40\% or clinical HF [3-5]. Their effects in AMI patients with EF $>40 \%$ have not been well documented. The clinical trials showing a long-term benefit of beta-blockers in patients with EF $>40 \%$ after AMI are still lacking, and clinical studies of RAS inhibitors in patients with stable coronary artery disease (CAD) without LV systolic dysfunction or clinical HF showed inconsistent results [6-8].

In the era of early coronary reperfusion therapy, patients with mildly reduced EF after AMI have been increasing. However, the role of beta-blockers or RAS inhibitors in such patients is still unclear because they may be classified as having either preserved or reduced EF. We have already reported that beta-blocker therapy at discharge was associated with better 1-year clinical outcomes in patients with mildly reduced $\mathrm{EF}(>40 \%,<50 \%)$ as well as with reduced $\mathrm{EF}(\leq 40 \%)$ 
medRxiv preprint doi: https://doi.org/10.1101/2022.03.01.22271686; this version posted March 2, 2022. The copyright holder for this preprint (which was not certified by peer review) is the author/funder, who has granted medRxiv a license to display the preprint in perpetuity.

It is made available under a CC-BY 4.0 International license.

after AMI, but not in patients with preserved EF ( $\geq 50 \%)$ [9]. This finding suggested that AMI patients with mildly reduced EF be managed similarly to those with reduced EF. Nevertheless, because of different baseline characteristics of those patients with vs. without beta-blocker therapy at discharge, this association needed to be confirmed in the propensity score-matched patients. Also the role of RAS inhibitor therapy in AMI patients with mildly reduced EF was not analyzed in the previous study.

This observational study aimed to define the association between the medical therapy with betablockers or RAS inhibitors at discharge and 2-year clinical outcomes in patients with mildly reduced EF after AMI after propensity score matching.

\section{Methods}

\section{Study population and data collection}

The Korea Acute Myocardial Infarction Registry-National Institute of Health (KAMIR-NIH) is a nation-wide, prospective, observational, and on-line registry of South Korea from 20 university hospitals. Patients who were hospitalized primarily for AMI and signed informed consents were consecutively enrolled from Nov 2011 to Oct 2015. This study was conducted according to the Declaration of Helsinki. The study protocol was approved by the ethics committee at Chonnam National University Hospital, Republic of Korea (IRB No. CNUH-2011-172) and the institutional review boards of all participating hospitals approved the study protocol. Written informed consents were obtained from participating patients or legal representative. Data were collected by the attending physician with the assistance of a trained clinical research coordinator, via a web-based case report form in the clinical data management system of the Korea NIH [9, 10]. LV systolic function was evaluated with echocardiography during the initial hospitalization. 
medRxiv preprint doi: https://doi.org/10.1101/2022.03.01.22271686; this version posted March 2, 2022. The copyright holder for this preprint (which was not certified by peer review) is the author/funder, who has granted medRxiv a license to display the preprint in perpetuity.

It is made available under a CC-BY 4.0 International license.

Patients, who did not undergo echocardiographic study, died during index hospitalization, had incomplete clinical data or had $\mathrm{EF} \leq 40 \%$ or $\geq 50 \%$, were excluded.

AMI was diagnosed when there was an evidence of myocardial necrosis (a rise and/or fall in cardiac biomarker, preferably cardiac troponin), and at least one of the following: (1) symptoms of ischemia, (2) new or presumed new significant ST-segment-T wave changes or a new left bundle branch block, (3) a development of pathologic Q waves in the ECG, (4) an imaging evidence of the new loss of viable myocardium or new regional wall motion abnormality, and (5) the identification of an intracoronary thrombus by angiography [11]. Coronary reperfusion included reperfusion by percutaneous coronary intervention (PCI), thrombolysis, or coronary artery bypass graft $(\mathrm{CABG})$, myocardial infarction with non-obstructed coronary arteries (MINOCA) [12], and myocardial bridge. RAS inhibitors included angiotensin-converting enzyme inhibitors (ACEi) and angiotensin receptor blockers (ARB).

\section{Clinical endpoints and definition}

The primary endpoint was 2-year major adverse cardiac events (MACE) which was a composite of cardiac death, myocardial infarction (MI), revascularization, and re-hospitalization due to HF. The secondary endpoints were each component of MACE, all-cause death, stroke, 2year major adverse cardiac and cerebrovascular events (MACCE) which was a composite of the primary endpoint and stroke, and 2-year MACE with non-cardiac death.

All deaths were considered to be associated with cardiac problems, unless a definite noncardiac cause was established. MI included re-infarction or recurrent MI [11]. Revascularization included repeated PCI or CABG on either target or non-target vessels. The staged PCI was excluded from revascularization. The clinical follow-ups were routinely performed at 6-, 12-, 24-, 
medRxiv preprint doi: https://doi.org/10.1101/2022.03.01.22271686; this version posted March 2, 2022. The copyright holder for this preprint (which was not certified by peer review) is the author/funder, who has granted medRxiv a license to display the preprint in perpetuity.

It is made available under a CC-BY 4.0 International license.

and 36-month by visiting the hospital or whenever any clinical events occurred. If patients did not visit the hospitals, the outcome data were assessed by telephone interview. Clinical events were not centrally adjudicated. The patient's physician identified all events and the principal investigator of each hospital confirmed them.

\section{Statistical analysis}

Because either beta-blocker or RAS inhibitor therapy was not randomized, propensity score matching was performed as a sensitivity analysis to minimize selection or predisposition bias. The propensity score was estimated using multiple logistic regression analysis with all variables in Table 1 and 2. Using a greedy nearest matching algorithm with 0.1 caliper width, each patient without beta-blockers or RAS inhibitors was matched to a maximum of two patients in betablocker or RAS inhibitor group. The efficacy of the propensity score model was assessed by estimating standardized differences for each covariate between groups.

Data were expressed as mean \pm standard deviation or median (interquartile range) for continuous variables, and as number (percentage) for categorical variables. Data were compared using unpaired t-test for continuous variables, and chi-square test for categorical variables. Survival curves for clinical endpoints and cumulative event rates with incidence rates per 100 patient-years were generated using Kaplan-Meier estimates. Hazard ratios (HR) and their 95\% confidence interval (CI) for each clinical endpoint were calculated using Cox proportional hazard analysis. In multivariate Cox regression analysis, age, sex, body mass index (BMI), hypertension, diabetes mellitus (DM), prior angina, prior MI, prior HF, current smoker, Killip class, estimated glomerular filtration rate (eGFR) by Modification of Diet in Renal Disease (MDRD) equation, LVEF, type of MI, coronary reperfusion, and medications (aspirin, P2Y12 
medRxiv preprint doi: https://doi.org/10.1101/2022.03.01.22271686; this version posted March 2, 2022. The copyright holder for this preprint (which was not certified by peer review) is the author/funder, who has granted medRxiv a license to display the preprint in perpetuity.

It is made available under a CC-BY 4.0 International license .

inhibitors, beta-blockers or RAS inhibitors, and statins) at discharge were included as covariates. Subgroups that were defined post-hoc according to demographic and clinical characteristics included age ( $<65, \geq 65-<80, \& \geq 80$ years), sex, hypertension, DM, prior MI, current smoker, Killip class $\geq 2$, eGFR $<60 \mathrm{~mL} / \mathrm{min} / 1.73 \mathrm{~m}^{2}$, EF ( $\leq 45 \%$ \& $\left.>45 \%\right)$, ST-elevation myocardial infarction (STEMI), and beta-blockers or RAS inhibitors at discharge.

All statistical analyses were performed with the statistical package SPSS version 23 (IBM Co, Armonk, NY, US) and R version 3.1.3 (R Foundation for Statistical Computing,Vienna, Austria). Clinical significance was defined as $P<0.05$.

\section{Results}

Total 13,624 consecutive patients were enrolled in the KAMIR-NIH. After excluding 10,720 patients $(1,153$ patients without echocardiographic data, 252 patients who died during index hospitalization, 19 patients with incomplete data, 1,670 patients with $\mathrm{EF} \leq 40 \%$, and 7,626 patients with $\mathrm{EF} \geq 50 \%$ ), 2,904 patients with $\mathrm{EF}>40 \%,<50 \%$ were analyzed in this study. They comprised $24 \%$ of patients who underwent echocardiographic study and survived the initial attack. Beta-blockers or RAS inhibitors were prescribed at the discretion of attending physicians. They were taken in 2,508 (86\%) and 2,316 patients (80\%) at discharge, respectively. After propensity score matching, 1,048 patients with or without beta-blockers at discharge and 1,559 patients with or without RAS inhibitors at discharge were selected (Fig 1). Overall reperfusion rate was $96 \%$, and PCI with drug-eluting stents was the main method of coronary reperfusion in both propensity-score matched cohorts (S1 and S2 Table).

In the entire cohort, patients without beta-blockers at discharge were older, and had lower BMI, more prior angina, more Killip class $\geq \mathrm{II}$, more eGFR $<60 \mathrm{~mL} / \mathrm{min} / 1.73 \mathrm{~m}^{2}$, less STEMI, and less 
medRxiv preprint doi: https://doi.org/10.1101/2022.03.01.22271686; this version posted March 2, 2022. The copyright holder for this preprint (which was not certified by peer review) is the author/funder, who has granted medRxiv a license to display the preprint in perpetuity.

It is made available under a CC-BY 4.0 International license .

coronary reperfusion. Less P2Y12 inhibitors, RAS inhibitors, or statins were prescribed at discharge (S3 Table). After propensity score matching, baseline characteristics of 685 patients with beta-blockers and 363 patients without beta-blockers at discharge were well balanced (Table 1). Likewise, patients without RAS inhibitors in the entire cohort were older, and had lower BMI, more prior angina, more eGFR $<60 \mathrm{~mL} / \mathrm{min} / 1.73 \mathrm{~m}^{2}$, less STEMI, and less coronary reperfusion. They were taking less P2Y12 inhibitors, beta-blockers, or statins at discharge (S4 Table). After propensity score matching, baseline characteristics of 1,003 patients with RAS inhibitors and 556 patients without RAS inhibitors at discharge were well balanced (Table 2).

In propensity-score matched cohorts, 2 -year follow-up rates were $96 \%$ and $92 \%$ in patients with and without beta-blockers at discharge, and 95\% and 94\% in patients with and without RAS inhibitors at discharge, respectively. Beta-blockers were discontinued at 1- and 2-year in 9\% and $18 \%$ of survived patients with beta-blockers at discharge, but were taken at 1- and 2-year in $45 \%$ and $41 \%$ of patients without them at discharge, respectively. RAS inhibitors were stopped at 1and 2 -year in $19 \%$ and $20 \%$ of survived patients with RAS inhibitors at discharge, but were taken at 1 - and 2 -year in $37 \%$ and $46 \%$ of patients without them at discharge, respectively. Patients with beta-blockers at discharge showed significantly lower 2-year MACE (8.7 vs. 12.8/100 patient-years) and HR was $0.68(95 \% \mathrm{CI} ; 0.50-0.93 ; P=0.015)$ after full adjustment, and this association was mainly driven by lower MI (HR 0.50; $95 \% \mathrm{CI} ; 0.26-0.95 ; P=0.035)$ and revascularization (HR 0.62; 95\% CI; 0.41-0.95; $P=0.030$ ) (Table 3, Fig 2). Likewise, 1-year MACE, cardiac deaths, and MI were significantly lower in patients with beta-blockers (S5 Table). The association between beta-blocker therapy at discharge and 2-year MACE appeared to be consistent across a series of subgroups (Fig 3). No significant interaction between EF $\leq 45 \%$ and $>45 \%$ in terms of any 2-year clinical endpoints was noted (S1 Fig). Beta-blocker therapy at 
medRxiv preprint doi: https://doi.org/10.1101/2022.03.01.22271686; this version posted March 2, 2022. The copyright holder for this preprint (which was not certified by peer review) is the author/funder, who has granted medRxiv a license to display the preprint in perpetuity.

It is made available under a CC-BY 4.0 International license .

discharge was also associated with lower 2-year MACE with non-cardiac death (Table 3). Carvedilol (50\%), bisoprolol (43\%) and nebivolol (5\%) were the major beta-blockers that prescribed at discharge (S6 Table). All beta-blockers were used in lower doses than those recommended in the guidelines. They showed comparable clinical outcomes without a significant interaction (S2 Fig).

However, no significant association of RAS inhibitors at discharge with 2-year clinical endpoints except re-hospitalization due to HF was observed after full adjustment (Table 4, Fig 4). Patients with RAS inhibitors at discharge were associated with lower 2-year rehospitalization due to HF (1.8 vs. 3.5/100 patient-years; HR $0.53 ; 95 \% \mathrm{CI}$; $0.33-0.86 ; P=0.010)$. Likewise, 1-year re-hospitalization due to HF was significantly lower in patients with RAS inhibitors at discharge (S7 Table). The association between RAS inhibitor therapy at discharge and 2-year re-hospitalization due to HF appeared to be consistent across a series of subgroups (S3 Fig), and no significant interaction between $\mathrm{EF} \leq 45 \%$ and $>45 \%$ was shown (S4 Fig). Perindopril (50\%) and ramipril (40\%) were the major ACEi's, and candesartan (35\%), losartan (24\%), telmisartan (20\%) and valsartan (14\%) were the major ARB's that prescribed at discharge (S8 Table). All RAS inhibitors were used in lower doses than those recommended in the guidelines. ACEi and ARB showed comparable clinical outcomes without a significant interaction (Fig 5).

Fig 1. Selection of patients for analysis. BB, beta-blockers; Echo, echocardiography; KAMIRNIH, Korean Acute Myocardial Infarction Registry-National Institute of Health; LVEF, left ventricular ejection fraction, PSM, propensity score-matching; RASI, inhibitors of reninangiotensin system. 
medRxiv preprint doi: https://doi.org/10.1101/2022.03.01.22271686; this version posted March 2, 2022. The copyright holder for this preprint (which was not certified by peer review) is the author/funder, who has granted medRxiv a license to display the preprint in perpetuity.

It is made available under a CC-BY 4.0 International license .

Fig 2. Kaplan-Meier curves and adjusted hazard ratios with $95 \%$ confidence intervals for 2-year events with vs. without beta-blockers at discharge in the propensity score-matched cohorts. (A) major adverse cardiac events (B) myocardial infarction (C) revascularization (D) cardiac death. BB, beta-blockers; CI, confidence interval; HR hazard ratio; MACE, major adverse cardiac events.

Fig 3. Adjusted hazard ratios of 2-year major adverse cardiac events for subgroups in the propensity score-matched cohort with vs. without beta-blockers at discharge. CI, confidence interval; eGFR, estimated glomerular filtration rate by MDRD equation; NSTEMI, non-ST elevation myocardial infarction; STEMI, ST-elevation myocardial infarction.

Fig 4. Kaplan-Meier curves and adjusted hazard ratios with $95 \%$ confidence intervals for 2-year events with vs. without inhibitors of renin-angiotensin system at discharge in the propensity score-matched cohorts. (A) major adverse cardiac events (B) heart failure (C) myocardial infarction (D) cardiac death. CI, confidence interval; HR hazard ratio; MACE, major adverse cardiac events; RASI, inhibitors of renin-angiotensin system.

Fig 5. Adjusted hazard ratios of 2-year re-hospitalization due to heart failure for angiotensin-converting enzyme inhibitors vs. angiotensin receptor blockers at discharge in the propensity score-matched cohort. ACEI, angiotensin-converting enzyme inhibitors; ARB, angiotensin receptor blockers; CI, confidence interval. 
medRxiv preprint doi: https://doi.org/10.1101/2022.03.01.22271686; this version posted March 2, 2022. The copyright holder for this preprint (which was not certified by peer review) is the author/funder, who has granted medRxiv a license to display the preprint in perpetuity.

It is made available under a CC-BY 4.0 International license. 
medRxiv preprint doi: https://doi.org/10.1101/2022.03.01.22271686; this version posted March 2, 2022. The copyright holder for this preprint (which was not certified by peer review) is the author/funder, who has granted medRxiv a license to display the preprint in perpetuity.

It is made available under a CC-BY 4.0 International license.

Table 1. Baseline characteristics of patients with vs. without beta-blockers at discharge after propensity-score matching

\begin{tabular}{|c|c|c|c|c|c|}
\hline & $\begin{array}{l}\text { All patients } \\
(\mathrm{N}=1,048)\end{array}$ & $\begin{array}{l}\text { With BB } \\
(\mathrm{N}=685)\end{array}$ & $\begin{array}{c}\text { Without BB } \\
(\mathrm{N}=363)\end{array}$ & SD & $P$ value \\
\hline Age (years) & $66.6 \pm 11.8$ & $66.4 \pm 11.3$ & $66.8 \pm 12.7$ & $<0.001$ & 0.635 \\
\hline Male & $736(70.2)$ & $480(70.1)$ & $256(70.5)$ & 0.027 & 0.887 \\
\hline Body mass index $\left(\mathrm{kg} / \mathrm{m}^{2}\right)$ & $23.42 \pm 3.21$ & $23.50 \pm 3.24$ & $23.27 \pm 3.17$ & -0.044 & 0.266 \\
\hline Hypertension & $502(47.9)$ & $325(47.4)$ & $177(48.8)$ & 0.025 & 0.697 \\
\hline Diabetes mellitus & $284(27.1)$ & $186(27.2)$ & $98(27.0)$ & 0.006 & 1.000 \\
\hline Prior angina pectoris & $105(10.0)$ & $65(9.5)$ & $40(11.0)$ & 0.035 & 0.450 \\
\hline Prior myocardial infarction & $94(9.0)$ & $63(9.2)$ & $31(8.5)$ & -0.014 & 0.820 \\
\hline Prior heart failure & $9(0.9)$ & $6(0.9)$ & $3(0.8)$ & $<0.001$ & 1.000 \\
\hline Prior stroke & $74(7.1)$ & $47(6.9)$ & $27(7.4)$ & 0.021 & 0.800 \\
\hline Current smoker & $397(37.9)$ & $262(38.2)$ & $135(37.2)$ & -0.014 & 0.789 \\
\hline Killip class $\geq$ II & $262(25.0)$ & $165(24.1)$ & $97(26.7)$ & 0.040 & 0.369 \\
\hline $\mathrm{eGFR}<60 \mathrm{~mL} / \mathrm{min} / 1.73 \mathrm{~m}^{2}$ & $228(21.8)$ & $149(21.8)$ & $79(21.8)$ & -0.010 & 1.000 \\
\hline Left ventricular EF (\%) & $45.7 \pm 2.5$ & $45.7 \pm 2.4$ & $45.5 \pm 2.5$ & -0.072 & 0.282 \\
\hline STEMI & $546(52.1)$ & $354(51.7)$ & $192(52.9)$ & 0.041 & 0.745 \\
\hline Coronary reperfusion $^{\mathrm{a}}$ & $1,005(95.9)$ & $656(95.8)$ & $349(96.1)$ & 0.023 & 0.871 \\
\hline \multicolumn{6}{|l|}{ Medications at discharge } \\
\hline Aspirin & $1,047(99.9)$ & $685(100)$ & $362(99.7)$ & -0.038 & 0.346 \\
\hline P2Y12 inhibitor & $1,022(95.6)$ & $655(95.6)$ & $347(95.6)$ & 0.015 & 1.000 \\
\hline RAS inhibitors & $627(59.8)$ & $420(61.3)$ & $207(57.0)$ & -0.019 & 0.186 \\
\hline Statins & $947(90.4)$ & $619(90.4)$ & $328(90.4)$ & 0.041 & 1.000 \\
\hline \multicolumn{6}{|c|}{$\begin{array}{l}\text { Values are mean } \pm \text { standard deviation or number }(\%) \text {. } \\
\text { Abbreviations: BB, beta-blockers; EF, ejection fraction; eGFR, estimated glomerular filtration rate by } \\
\text { MDRD equation; RAS, renin-angiotensin system; SD, standardized difference; STEMI, ST elevation } \\
\text { myocardial infarction. } \\
\text { ancludes reperfusion by percutaneous coronary intervention, thrombolysis, coronary artery bypass } \\
\text { graft, or myocardial infarction with non-obstructed coronary arteries (MINOCA). }\end{array}$} \\
\hline
\end{tabular}


medRxiv preprint doi: https://doi.org/10.1101/2022.03.01.22271686; this version posted March 2, 2022. The copyright holder for this preprint (which was not certified by peer review) is the author/funder, who has granted medRxiv a license to display the preprint in perpetuity.

It is made available under a CC-BY 4.0 International license .

Table 2. Baseline characteristics of patients with vs. without inhibitors of renin-angiotensin system at discharge after propensity-score matching

\begin{tabular}{|c|c|c|c|c|c|}
\hline & $\begin{array}{l}\text { All patients } \\
(\mathrm{N}=1,559)\end{array}$ & $\begin{array}{l}\text { With RASI } \\
(\mathrm{N}=1,003)\end{array}$ & $\begin{array}{l}\text { Without RASI } \\
\qquad(\mathrm{N}=556)\end{array}$ & SD & $P$ value \\
\hline Age (years) & $65.2 \pm 12.5$ & $65.0 \pm 12.4$ & $65.5 \pm 12.6$ & 0.002 & 0.429 \\
\hline Male & $1,129(72.4)$ & $723(72.1)$ & $406(73.0)$ & 0.032 & 0.723 \\
\hline Body mass index $\left(\mathrm{kg} / \mathrm{m}^{2}\right)$ & $23.42 \pm 3.07$ & $23.42 \pm 3.01$ & $23.43 \pm 3.17$ & 0.033 & 0.960 \\
\hline Hypertension & $712(45.7)$ & $457(45.6)$ & $255(45.9)$ & 0.007 & 0.916 \\
\hline Diabetes mellitus & $460(29.5)$ & $292(29.1)$ & $168(30.2)$ & 0.017 & 0.643 \\
\hline Prior angina pectoris & $143(9.2)$ & $84(8.4)$ & $59(10.6)$ & 0.052 & 0.144 \\
\hline Prior myocardial infarction & $139(8.9)$ & $90(9.0)$ & $49(8.8)$ & $<0.001$ & 1.000 \\
\hline Prior heart failure & $21(1.3)$ & $14(1.4)$ & $7(1.3)$ & -0.025 & 1.000 \\
\hline Prior stroke & $113(7.2)$ & $72(7.2)$ & $41(7.4)$ & -0.010 & 0.919 \\
\hline Current smoker & $605(38.8)$ & $392(39.1)$ & $213(38.3)$ & 0.004 & 0.786 \\
\hline Killip class $\geq$ II & $358(23.0)$ & $230(22.9)$ & $128(23.0)$ & -0.011 & 1.000 \\
\hline eGFR $<60 \mathrm{~mL} / \mathrm{min} / 1.73 \mathrm{~m}^{2}$ & $329(21.1)$ & $206(20.5)$ & $123(22.1)$ & 0.009 & 0.476 \\
\hline Left ventricular EF (\%) & $45.5 \pm 2.5$ & $45.5 \pm 2.5$ & $45.6 \pm 2.5$ & 0.025 & 0.613 \\
\hline STEMI & $920(59.0)$ & $603(60.1)$ & $317(57.0)$ & -0.031 & 0.237 \\
\hline Coronary reperfusion ${ }^{a}$ & $1,504(96.5)$ & $969(96.6)$ & $535(96.2)$ & $<0.001$ & 0.671 \\
\hline \multicolumn{6}{|l|}{ Medications at discharge } \\
\hline Aspirin & $1,556(99.8)$ & $1,001(99.8)$ & $555(99.8)$ & 0.015 & 1.000 \\
\hline P2Y12 inhibitor & $1,505(96.5)$ & $969(96.6)$ & $536(96.4)$ & 0.016 & 0.885 \\
\hline Beta-blockers & $1,199(76.9)$ & $800(79.8)$ & $399(71.8)$ & -0.008 & $<0.001$ \\
\hline Statins & $1,439(92.3)$ & $931(92.8)$ & $508(91.4)$ & -0.015 & 0.322 \\
\hline \multicolumn{6}{|c|}{ Values are mean \pm standard deviation or number $(\%)$} \\
\hline \multicolumn{6}{|c|}{$\begin{array}{l}\text { RASI, inhibitors of renin-angiotensin system; SD, standardized difference; STEMI, ST elevation } \\
\text { myocardial infarction. }\end{array}$} \\
\hline \multicolumn{6}{|c|}{$\begin{array}{l}\text { ancludes reperfusion by percutaneous coronary intervention, thrombolysis, coronary artery bypass } \\
\text { graft, myocardial bridge, or myocardial infarction with non-obstructed coronary arteries (MINOCA). }\end{array}$} \\
\hline
\end{tabular}


Table 3. Multivariate Cox-proportional hazard analysis of 2-year events in patients with vs. without beta-blockers at discharge after propensity-score matching

\begin{tabular}{|c|c|c|c|c|}
\hline Events & $\begin{array}{l}\text { With BB } \\
(\mathrm{N}=685)\end{array}$ & $\begin{array}{c}\text { Without BB } \\
(\mathrm{N}=363)\end{array}$ & $\begin{array}{c}\text { Hazard ratio } \\
(95 \% \mathrm{CI})\end{array}$ & $P$ value \\
\hline MACE & $103(8.7)$ & $73(12.8)$ & $0.68(0.50-0.93)$ & 0.015 \\
\hline Cardiac death & $32(2.5)$ & $25(4.0)$ & $0.67(0.38-1.16)$ & 0.154 \\
\hline All-cause death & $54(4.3)$ & $38(6.1)$ & $0.69(0.45-1.05)$ & 0.085 \\
\hline Myocardial infarction & $20(1.6)$ & $19(3.1)$ & $0.50(0.26-0.95)$ & 0.035 \\
\hline Revascularization & $50(4.1)$ & $38(6.5)$ & $0.62(0.41-0.95)$ & 0.030 \\
\hline Heart failure $^{b}$ & $29(2.4)$ & $14(2.3)$ & $1.06(0.55-2.03)$ & 0.868 \\
\hline Stroke & $12(1.0)$ & $9(1.4)$ & $0.69(0.29-1.66)$ & 0.409 \\
\hline MACCE & $111(9.5)$ & $78(13.7)$ & $0.70(0.52-0.94)$ & 0.017 \\
\hline MACE with NCD & $124(10.5)$ & $82(14.3)$ & $0.72(0.54-0.96)$ & 0.025 \\
\hline \multicolumn{5}{|c|}{$\begin{array}{l}\text { aAdjusted for age, sex, body mass index, hypertension, diabetes mellitus, prior angina, prior MI, prior } \\
\text { heart failure, current smoker, Killip class, estimated glomerular filtration rate, left ventricular ejection } \\
\text { fraction, type of myocardial infarction, coronary reperfusion, and medications (aspirin, P2Y12 } \\
\text { inhibitors, inhibitors of renin-angiotensin system and statins) at discharge } \\
\text { be-hospitalization due to heart failure }\end{array}$} \\
\hline
\end{tabular}


medRxiv preprint doi: https://doi.org/10.1101/2022.03.01.22271686; this version posted March 2, 2022. The copyright holder for this preprint (which was not certified by peer review) is the author/funder, who has granted medRxiv a license to display the preprint in perpetuity.

It is made available under a CC-BY 4.0 International license.

Table 4. Multivariate Cox-proportional hazard analysis of 2-year events patients with vs. without inhibitors of renin-angiotensin system at discharge after propensity-score matching

\begin{tabular}{|c|c|c|c|c|}
\hline Events & $\begin{array}{l}\text { With RASI } \\
(\mathrm{N}=1,003)\end{array}$ & $\begin{array}{l}\text { Without RASI } \\
(\mathrm{N}=556)\end{array}$ & $\begin{array}{c}\text { Hazard ratio } \\
(95 \% \mathrm{CI})\end{array}$ & $P$ value \\
\hline MACE & $151(8.9)$ & $89(9.6)$ & $0.95(0.73-1.23)$ & 0.676 \\
\hline Cardiac death & $42(2.3)$ & $27(2.7)$ & $0.91(0.55-1.49)$ & 0.700 \\
\hline All-cause death & $75(4.1)$ & $45(4.5)$ & $0.96(0.66-1.39)$ & 0.809 \\
\hline Myocardial infarction & $28(1.6)$ & $18(1.8)$ & $0.91(0.50-1.67)$ & 0.763 \\
\hline Revascularization & $83(4.8)$ & $39(4.0)$ & $1.22(0.83-1.79)$ & 0.306 \\
\hline Heart failure $^{b}$ & $33(1.8)$ & $34(3.5)$ & $0.53(0.33-0.86)$ & 0.010 \\
\hline Stroke & $15(0.8)$ & $12(1.2)$ & $0.72(0.33-1.55)$ & 0.395 \\
\hline MACCE & $163(9.7)$ & $98(10.6)$ & $0.92(0.71-1.18)$ & 0.514 \\
\hline MACE with NCD & $182(10.7)$ & $102(11.0)$ & $0.99(0.78-1.27)$ & 0.954 \\
\hline \multicolumn{5}{|c|}{$\begin{array}{l}\text { Abbreviations: CI, confidence interval; MACCE, major adverse cardiac and cerebrovascular event; } \\
\text { MACE, major adverse cardiac event; NCD, Non-cardiac death; RASI, inhibitors of renin- } \\
\text { angiotensin system. }\end{array}$} \\
\hline \multicolumn{5}{|c|}{$\begin{array}{l}\text { aAdjusted for age, sex, body mass index, hypertension, diabetes mellitus, prior angina, prior MI, } \\
\text { prior heart failure, current smoker, Killip class, estimated glomerular filtration rate, left ventricular } \\
\text { ejection fraction, type of myocardial infarction, coronary reperfusion, and medications (aspirin, } \\
\text { P2Y12 inhibitors, beta-blockers and statins) at discharge }\end{array}$} \\
\hline
\end{tabular}

\section{Discussion}

The main finding of this study is that the medical therapy with beta-blockers or RAS inhibitors at discharge was associated with better 2-year clinical outcomes without significant interaction between $\mathrm{EF} \leq 45 \%$ and $>45 \%$ in patients with mildly reduced EF after AMI in the era of early 
medRxiv preprint doi: https://doi.org/10.1101/2022.03.01.22271686; this version posted March 2, 2022. The copyright holder for this preprint (which was not certified by peer review) is the author/funder, who has granted medRxiv a license to display the preprint in perpetuity.

It is made available under a CC-BY 4.0 International license .

coronary reperfusion and the contemporary other optimal medical therapy with antiplatelet agents and statins.

The prevalence of HFmrEF in the registries and clinical trials of HF patients was $14-23 \%$ [13]. Similarly to HFrEF, the most common etiology of HFmrEF was an ischemic heart disease (IHD) [14], and prior MI was an important predictor of HFmrEF [15]. Our data showed that a quarter of patients with AMI had mildly reduced EF. All-cause mortality of patients with HFmrEF was intermediate between HFrEF and HFpEF [14, 15], and CAD indicated a higher risk of death in HFmrEF [16]. Therefore, patients with mildly reduced EF as well as reduced EF after AMI should be managed with an optimal medical therapy to reduce cardiovascular mortality and morbidity.

Beta-blockers' benefit in patients with HFrEF was clearly shown in previous clinical trials, and evidence-proven beta-blockers are strongly recommended in the guidelines $[1,2,17,18]$. However, the role of beta-blockers in patients with HFpEF or HFmrEF was not clearly proven except one meta-analysis of clinical trials which showed $41 \%$ and $52 \%$ reduction of all-cause and cardiac mortality in patients with HFmrEF in sinus rhythm [19]. But the median EF of 40\% (interquartile range $40-43 \%$ ) in this meta-analysis could not provide the sufficient evidence to support the use of beta-blockers in patients with HFmrEF, especially when EF is $>45 \%$. In HF registries, beta-blocker therapy was associated with lower all-cause mortality in patients with HFmrEF [16, 20].

Likewise, no randomized clinical trials of beta-blockers in AMI patients with mildly reduced EF are available so far. In this regard, registry data may provide evidence about an optimal medical therapy in these patients despite the inherent limitations. Previous registry data showed no association of beta-blocker therapy with reduced mortality among survivors of AMI without 
medRxiv preprint doi: https://doi.org/10.1101/2022.03.01.22271686; this version posted March 2, 2022. The copyright holder for this preprint (which was not certified by peer review) is the author/funder, who has granted medRxiv a license to display the preprint in perpetuity.

It is made available under a CC-BY 4.0 International license .

HF or LV systolic dysfunction $(\mathrm{EF}<30-40 \%)[21,22]$. In our registry, beta-blocker therapy at discharge was associated with lower 2-year MACE in AMI patients with mildly reduced EF without significant interaction between $\mathrm{EF} \leq 45 \%$ and $>45 \%$. This association was mainly driven by lower MI, and revascularization which was partially associated with recurrent MI. AMI patients with mildly reduced EF have scarred or non-viable myocardium to some extent, and in this clinical setting, beta-blocker therapy may be effective in reducing fatal arrhythmia, myocardial ischemia, or recurrent MI [9, 22]. Our data suggest that beta-blocker therapy be considered in patients with mildly reduced EF after AMI.

In MI patients with reduced EF or clinical HF, ACEi therapy was shown to reduce rates of death, MI and re-admission for HF [4], and ARB was non-inferior to ACEi with regard to allcause mortality and combined end point of cardiovascular death, recurrent MI or hospitalization for HF [5]. In patients with HFmrEF, a registry data showed RAS inhibitors were associated with lower all-cause mortality [16], and in re-analyzed data of the Candesartan in Heart FailureAssessment of Reduction in Mortality and Morbidity (CHARM) Programme, candesartan significantly reduced hospitalization for HF in HFmrEF, but not in HFpEF [23].

In patients with stable CAD without LV systolic dysfunction ( $\mathrm{EF}<40 \%$ ) or clinical $\mathrm{HF}$, two large clinical trials showed ACEi's role in reducing cardiovascular death and MI [6, 7], but other trial failed to provide further clinical benefit [8]. ARB in patients with stable CAD also did not reduce cardiac death, MI or hospitalization for HF [24]. This inconsistent result may be caused by the different characteristics of enrolled patients and the rates of clinical events which were affected by the intensive risk modulating medical therapy such as anti-platelet agents, betablockers or statins, and optimal coronary revascularization [8]. In a meta-analysis of clinical trials in stable CAD without HF, RAS inhibitors lowered all-cause mortality, cardiovascular 
medRxiv preprint doi: https://doi.org/10.1101/2022.03.01.22271686; this version posted March 2, 2022. The copyright holder for this preprint (which was not certified by peer review) is the author/funder, who has granted medRxiv a license to display the preprint in perpetuity.

It is made available under a CC-BY 4.0 International license.

mortality and HF when compared with placebo, but their benefit on all-cause and cardiovascular mortality was shown only in trials with high control event rates [25]. However, the role of RAS inhibitors in AMI patients with mildly reduced EF has not been proven yet in randomized clinical trials. Only a registry data of HFmrEF showed the mortality benefit of RAS inhibitor therapy in patients with CAD [16]. In our registry, RAS inhibitor therapy at discharge was associated with lower 2-year re-hospitalization due to HF in AMI patients with mildly reduced EF without significant interaction between $\mathrm{EF} \leq 45 \%$ and $>45 \%$ despite early coronary reperfusion and other guideline-directed medical therapy, and this outcome was comparable between ACEi and ARB. HFmrEF may be in the transition stage that becomes to improve to HFpEF or to progress to HFrEF, and IHD etiology was associated with a decrease in EF [20]. The activation of RAS after AMI causes LV dilatation and dysfunction which may induce clinical HF, and this remodeling process was shown to be attenuated by RAS inhibition.[4, 5] Our data suggest that RAS inhibitor therapy be considered in AMI patients with mildly reduced EF to prevent HF hospitalization.

\section{Limitations}

First, this study analyzed a non-randomized, observational registry data. Beta-blockers or RAS inhibitors were prescribed at the discretion of an attending physician. The information why physicians did not prescribe beta-blockers or RAS inhibitors to some patients at discharge was not available. Although we tried to adjust the potential confounding factors by multivariable and a propensity score-matched analysis, other unrecorded or residual confounders as well as selection bias could not be completely controlled. Therefore, our results should be interpreted with caution. Second, because patients' medications were recorded only at discharge, 1-year and 
medRxiv preprint doi: https://doi.org/10.1101/2022.03.01.22271686; this version posted March 2, 2022. The copyright holder for this preprint (which was not certified by peer review) is the author/funder, who has granted medRxiv a license to display the preprint in perpetuity.

It is made available under a CC-BY 4.0 International license .

2-year, we could not ascertain whether patients actually obtained them, took them as prescribed, and adhered for two years. In addition, a large cross-over was observed in patients without betablockers or RAS inhibitors at discharge, and $41 \%$ and $46 \%$ of those patients were taking betablockers and RAS inhibitors at 2-year, respectively. However, despite this cross-over, taking beta-blockers or RAS inhibitors from the hospital discharge was associated with improved clinical outcomes. Third, beta-blockers and RAS inhibitors at discharge were prescribed at only a quarter to half of maximal dose recommended in the guidelines, and the individual dose at the time of clinical events was not available. However, in an American registry of AMI, betablockers were prescribed less than a quarter of maximal dose at discharge in $60 \%$ of patients, and the lowest mortality was observed in $>12.5 \%-25 \%$ dose group [26]. In the Swedish Heart Failure Registry, RAS inhibitors of $>50 \%$ of target dose, compared with $\leq 50 \%$ of target dose, showed better mortality benefit in patients with $\mathrm{HFpEF}(\mathrm{EF} \geq 40 \%)$, but over $70 \%$ of patients were prescribed $\leq 50 \%$ of target dose [27]. The lower than maximal recommended dose may be a usual prescription pattern in "real-world" registries, and the optimal dose of beta-blockers or RAS inhibitors in patients with AMI with mildly reduced EF needs to be confirmed in a randomized clinical trial.

\section{Conclusions}

In patients with mildly reduced EF after AMI, the medical therapy with beta-blockers or RAS inhibitors at discharge were associated with better 2-year clinical outcomes without significant interaction between $\mathrm{EF} \leq 45 \%$ and $>45 \%$. These data suggest that long-term beta-blocker or RAS inhibitor therapy need to be considered in AMI patients with mildly reduced EF. 
medRxiv preprint doi: https://doi.org/10.1101/2022.03.01.22271686; this version posted March 2, 2022. The copyright holder for this preprint (which was not certified by peer review) is the author/funder, who has granted medRxiv a license to display the preprint in perpetuity.

\section{Acknowledgements}

We appreciate the contribution of other KAMIR-NIH investigators: Tae Hoon Ahn, Ki-Bae Seung, Chong-Jin Kim, Shung Chull Chae, Jin-Yong Hwang, Seung-Woon Rha, Kwang Soo Cha, Hyo-Soo Kim, Hyeon-Cheol Gwon, Seok Kyu Oh, Junghan Yoon, In-Whan Seong, Kyung-Kuk Hwang, Doo-Il Kim

\section{Supporting information}

S1 Table. Reperfusion rates and methods in patients with vs. without beta-blockers at discharge after propensity score matching S2 Table. Reperfusion rates and methods in patients with vs. without inhibitors of reninangiotensin system at discharge after propensity score matching

S3 Table. Baseline characteristics of patients with vs. without beta-blockers at discharge in the entire cohort

S4 Table. Baseline characteristics of patients with vs. without inhibitors of reninangiotensin system at discharge in the entire cohort

S5 Table. Multivariate Cox-proportional hazard analysis of 1-year events in patients with vs. without beta-blockers at discharge after propensity score matching S6 Table. Generic names and doses of beta-blockers that prescribed at discharge in propensity-score matched patients

S7 Table. Multivariate Cox-proportional hazard analysis of 1-year events in patients with vs. without inhibitors of renin-angiotensin system at discharge after propensity score matching 
medRxiv preprint doi: https://doi.org/10.1101/2022.03.01.22271686; this version posted March 2, 2022. The copyright holder for this preprint (which was not certified by peer review) is the author/funder, who has granted medRxiv a license to display the preprint in perpetuity.

It is made available under a CC-BY 4.0 International license .

S8 Table. Generic names and doses of inhibitors of renin-angiotensin system that prescribed at discharge in propensity-score matched patients

S1 Fig. Adjusted hazard ratios of 2-year events according to left ventricular ejection fraction $\leq 45 \%$ vs. $>45 \%$ in the propensity score-matched cohort with or without betablockers at discharge. CI, confidence interval; LVEF, left ventricular ejection fraction; MACCE, major adverse cardiac and cerebrovascular event; MACE, major adverse cardiac event. S2 Fig. Adjusted hazard ratios of 2-year major adverse cardiac events in the propensity score-matched cohort according to generic names of beta-blockers at discharge. (A) adjusted hazard ratios with vs. without beta-blockers. (B) adjusted hazard ratios among betablockers. CI, confidence interval.

S3 Fig. Adjusted hazard ratios of 2-year re-hospitalization due to heart failure for subgroups in the propensity score-matched cohort with vs. without inhibitors of reninangiotensin system at discharge. CI, confidence interval; eGFR, estimated glomerular filtration rate by MDRD equation; NSTEMI, non-ST elevation myocardial infarction; STEMI, STelevation myocardial infarction.

S4 Fig. Adjusted hazard ratios of 2-year events according to left ventricular ejection fraction $\leq 45 \%$ vs. $>45 \%$ in the propensity score-matched cohort with or without inhibitors of renin-angiotensin system at discharge. $\mathrm{CI}$, confidence interval; LVEF, left ventricular ejection fraction; MACCE, major adverse cardiac and cerebrovascular event; MACE, major adverse cardiac event.

\section{Author Contributions}


medRxiv preprint doi: https://doi.org/10.1101/2022.03.01.22271686; this version posted March 2, 2022. The copyright holder for this preprint (which was not certified by peer review) is the author/funder, who has granted medRxiv a license to display the preprint in perpetuity.

It is made available under a CC-BY 4.0 International license.

Conceptualization: Seung-Jae Joo, Hyeung Keun Park, Chang-Hwan Yoon, Jung-Hee Lee,

Seung-Ho Hur, Jei Keon Chae, Myung Ho Jeong

Data curation: Seung-Jae Joo, Song-Yi Kim, Jae-Geun Lee, Joon-Hyouk Choi, Jong Wook

Beom, Ki Yung Boo

Formal analysis: Seung-Jae Joo, Joon-Hyouk Choi. Hyeung Keun Park.

Funding acquisition: Myung Ho Jeong.

Investigation: Seung-Jae Joo, Chang-Hwan Yoon, Jung-Hee Lee, Seung-Ho Hur, Jei Keon Chae, Myung Ho Jeong

Methodology: Seung-Jae Joo, Hyeung Keun Park

Project administration: Seung-Jae Joo, Myung Ho Jeong

Resources: Seung-Jae Joo, Myung Ho Jeong.

Software: Seung-Jae Joo, Joon-Hyouk Choi. Hyeung Keun Park

Supervision: Seung-Jae Joo.

Validation: Hyeung Keun Park.

Visualization: Seung-Jae Joo.

Writing - original draft: Seung-Jae Joo.

Writing - review \& editing: : Seung-Jae Joo, Song-Yi Kim, Jae-Geun Lee, Joon-Hyouk Choi,

Jong Wook Beom, Ki Yung Boo,. Hyeung Keun Park, Chang-Hwan Yoon, Jung-Hee Lee,

Seung-Ho Hur, Jei Keon Chae, Myung Ho Jeong 
medRxiv preprint doi: https://doi.org/10.1101/2022.03.01.22271686; this version posted March 2, 2022. The copyright holder for this preprint (which was not certified by peer review) is the author/funder, who has granted medRxiv a license to display the preprint in perpetuity.

It is made available under a CC-BY 4.0 International license .

\section{References}

1. Ponikowski P, Voors AA, Anker SD, Bueno H, Cleland JGF, Coats AJS, et al. 2016 ESC

Guidelines for the diagnosis and treatment of acute and chronic heart failure: The Task Force for the diagnosis and treatment of acute and chronic heart failure of the European Society of

Cardiology (ESC) Developed with the special contribution of the Heart Failure Association

(HFA) of the ESC. Eur Heart J. 2016;37:2129-2200.

2. McDonagh TA, Metra M, Adamo M, Gardner RS, Baumbach A, Böhm M, et al; ESC

Scientific Document Group. 2021 ESC Guidelines for the diagnosis and treatment of acute and chronic heart failure. Eur Heart J. 2021;42:3599-3726.

3. The CAPRICON Investigators. Effect of carvedilol on outcome after myocardial infarction in patients with left-ventricular dysfunction: the CAPRICORN randomised trial. Lancet. 2001;357:1385-1390.

4. Flather MD, Yusuf S, Køber L, Pfeffer M, Hall A, Murray G, et al. Long-term ACE-inhibitor therapy in patients with heart failure or left-ventricular dysfunction: a systematic overview of data from individual patients. ACE-Inhibitor Myocardial Infarction Collaborative Group. Lancet. 2000;355:1575-1581.

5. Pfeffer MA, McMurray JJ, Velazquez EJ, Rouleau JL, Køber L, Maggioni AP, et al; Valsartan in Acute Myocardial Infarction Trial Investigators. Valsartan, captopril, or both in myocardial infarction complicated by heart failure, left ventricular dysfunction, or both. $N$ Engl J Med. 
medRxiv preprint doi: https://doi.org/10.1101/2022.03.01.22271686; this version posted March 2, 2022. The copyright holder for this preprint (which was not certified by peer review) is the author/funder, who has granted medRxiv a license to display the preprint in perpetuity.

It is made available under a CC-BY 4.0 International license .

2003;349:1893-1906.

6. Heart Outcomes Prevention Evaluation Study Investigators, Yusuf S, Sleight P, Pogue J, Bosch J, Davies R, Dagenais G. Effects of an angiotensin-converting- enzyme inhibitor, ramipril, on cardiovascular events in high-risk patients. N Engl J Med. 2000;342:145-153.

7. Fox KM; EURopean trial On reduction of cardiac events with Perindopril in stable coronary Artery disease Investigators. Efficacy of perindopril in reduction of cardiovascular events among patients with stable coronary artery disease: randomised, double-blind, placebo-controlled, multicentre trial (the EUROPA study). Lancet. 2003;362:782-788.

8. Braunwald E, Domanski MJ, Fowler SE, Geller NL, Gersh BJ, Hsia J, et al; PEACE Trial Investigators. Angiotensin-converting-enzyme inhibition in stable coronary artery disease. $N$ Engl J Med. 2004;351:2058-2068.

9. Joo SJ, Kim SY, Choi JH, Park HK, Beom JW, Lee JG, et al; KAMIR-NIH registry investigators. Effect of beta-blocker therapy in patients with or without left ventricular systolic dysfunction after acute myocardial infarction. Eur Heart J Cardiovasc Pharmacother. $2021 ; 7: 475-482$

10. Kim JH, Chae SC, Oh DJ, Kim HS, Kim YJ, Ahn Y, et al. Multicenter Cohort Study of Acute Myocardial Infarction in Korea- Interim Analysis of the Korea Acute Myocardial Infarction Registry-National Institutes of Health Registry. Circ J. 2016;80:1427-1436. 
medRxiv preprint doi: https://doi.org/10.1101/2022.03.01.22271686; this version posted March 2, 2022. The copyright holder for this preprint (which was not certified by peer review) is the author/funder, who has granted medRxiv a license to display the preprint in perpetuity.

It is made available under a CC-BY 4.0 International license .

11. Thygesen K, Alpert JS, Jaffe AS, Simoons ML, Chaitman BR, White HD. Third universal definition of myocardial infarction. Circulation. 2012;126:2020-2035.

12. Ibanez B, James S, Agewall S, Antunes MJ, Bucciarelli-Ducci C, Bueno H, et al. 2017 ESC Guidelines for the management of acute myocardial infarction in patients presenting with STsegment elevation: The Task Force for the management of acute myocardial infarction in patients presenting with ST-segment elevation of the European Society of Cardiology (ESC). Eur Heart J. 2018;39:119-177.

13. Branca L, Sbolli M, Metra M, Fudim M. Heart failure with mid-range ejection fraction: pro and cons of the new classification of Heart Failure by European Society of Cardiology guidelines. ESC Heart Fail. 2020;7:381-399.

14. Chioncel O, Lainscak M, Seferovic PM, Anker SD, Crespo-Leiro MG, Harjola VP, et al. Epidemiology and one-year outcomes in patients with chronic heart failure and preserved, midrange and reduced ejection fraction: an analysis of the ESC Heart Failure Long-Term Registry. Eur J Heart Fail. 2017;19:1574-1585.

15. Bhambhani V, Kizer JR, Lima JAC, van der Harst P, Bahrami H, Nayor M, et al. Predictors and outcomes of heart failure with mid-range ejection fraction. Eur J Heart Fail. 2018;20:651659. 
medRxiv preprint doi: https://doi.org/10.1101/2022.03.01.22271686; this version posted March 2, 2022. The copyright holder for this preprint (which was not certified by peer review) is the author/funder, who has granted medRxiv a license to display the preprint in perpetuity.

It is made available under a CC-BY 4.0 International license .

16. Koh AS, Tay WT, Teng THK, Vedin O, Benson L, Dahlstrom U, et al. A comprehensive population-based characterization of heart failure with mid-range ejection fraction. Eur J Heart Fail. 2017;19:1624-1634.

17. Yancy CW, Jessup M, Bozkurt B, Butler J, Casey DE Jr, Drazner MH, et al. 2013

ACCF/AHA guideline for the management of heart failure: executive summary: a report of the American College of Cardiology Foundation/American Heart Association Task Force on practice guidelines. Circulation. 2013;128:1810-1852.

18. Maddox TM, Januzzi JL Jr, Allen LA, Breathett K, Butler J, Davis LL, et al. 2021 Update to the 2017 ACC Expert Consensus Decision Pathway for Optimization of Heart Failure Treatment: Answers to 10 Pivotal Issues About Heart Failure With Reduced Ejection Fraction: A Report of the American College of Cardiology Solution Set Oversight Committee. J Am Coll Cardiol. 2021;77:772-810.

19. Cleland JGF, Bunting KV, Flather MD, Altman DG, Holmes J, Coats AJS, et al. Betablockers for heart failure with reduced, mid-range, and preserved ejection fraction: an individual patient-level analysis of double-blind randomized trials. Eur Heart J. 2018;39:26-35.

20. Tsuji K, Sakata Y, Nochioka K, Miura M, Yamauchi T, Onose T, et al; CHART-2 Investigators. Characterization of heart failure patients with mid-range left ventricular ejection fraction-a report from the CHART-2 Study. Eur J Heart Fail. 2017;19:1258-1269. 
medRxiv preprint doi: https://doi.org/10.1101/2022.03.01.22271686; this version posted March 2, 2022. The copyright holder for this preprint (which was not certified by peer review) is the author/funder, who has granted medRxiv a license to display the preprint in perpetuity.

It is made available under a CC-BY 4.0 International license .

21. Puymirat E, Riant E, Aissaoui N, Soria A, Ducrocq G, Coste P, et al. $\beta$-blockers and mortality after myocardial infarction in patients without heart failure: multicenter prospective cohort study. BMJ. 2016;354:i4801.

22. Dondo TB, Hall M, West RM, Jernberg T, Lindahl B, Bueno H, et al. $\beta$-blockers and mortality after acute myocardial infarction in patients without heart failure or ventricular dysfunction. J Am Coll Cardiol. 2017;69:2710-2720.

23. Lund LH, Claggett B, Liu J, Lam CS, Jhund PS, Rosano GM, et al. Heart failure with midrange ejection fraction in CHARM: characteristics, outcomes and effect of candesartan across the entire ejection fraction spectrum. Eur J Heart Fail. 2018;20:1230-1239.

24. Telmisartan Randomised AssessmeNt Study in ACE iNtolerant subjects with cardiovascular Disease (TRANSCEND) Investigators, Yusuf S, Teo K, Anderson C, Pogue J, Dyal L, Copland I, et al. Effects of the angiotensin-receptor blocker telmisartan on cardiovascular events in highrisk patients intolerant to angiotensin-converting enzyme inhibitors: a randomized controlled trial. Lancet. 2008;372:1174-1183.

25. Bangalore S, Fakheri R, Wandel S, Toklu B, Wandel J, Messerli FH. Renin angiotensin system inhibitors for patients with stable coronary artery disease without heart failure: systematic review and meta-analysis of randomized trials. BMJ. 2017;356:j4.

26. Goldberger JJ, Bonow RO, Cuffe M, Liu L, Rosenberg Y, Shah PK, et al. Effect of beta- 
medRxiv preprint doi: https://doi.org/10.1101/2022.03.01.22271686; this version posted March 2, 2022. The copyright holder for this preprint (which was not certified by peer review) is the author/funder, who has granted medRxiv a license to display the preprint in perpetuity.

It is made available under a CC-BY 4.0 International license.

blocker dose on survival after acute myocardial infarction. J Am Coll Cardiol. 2015;66:14311441.

27. Lund LH, Benson L, Dahlström U, Edner M. Association between use of renin-angiotensin system antagonists and mortality in patients with heart failure and preserved ejection fraction.

JAMA. 2012;308:2108-2017. 


\section{3,624 KAMIR-NIH Registry}

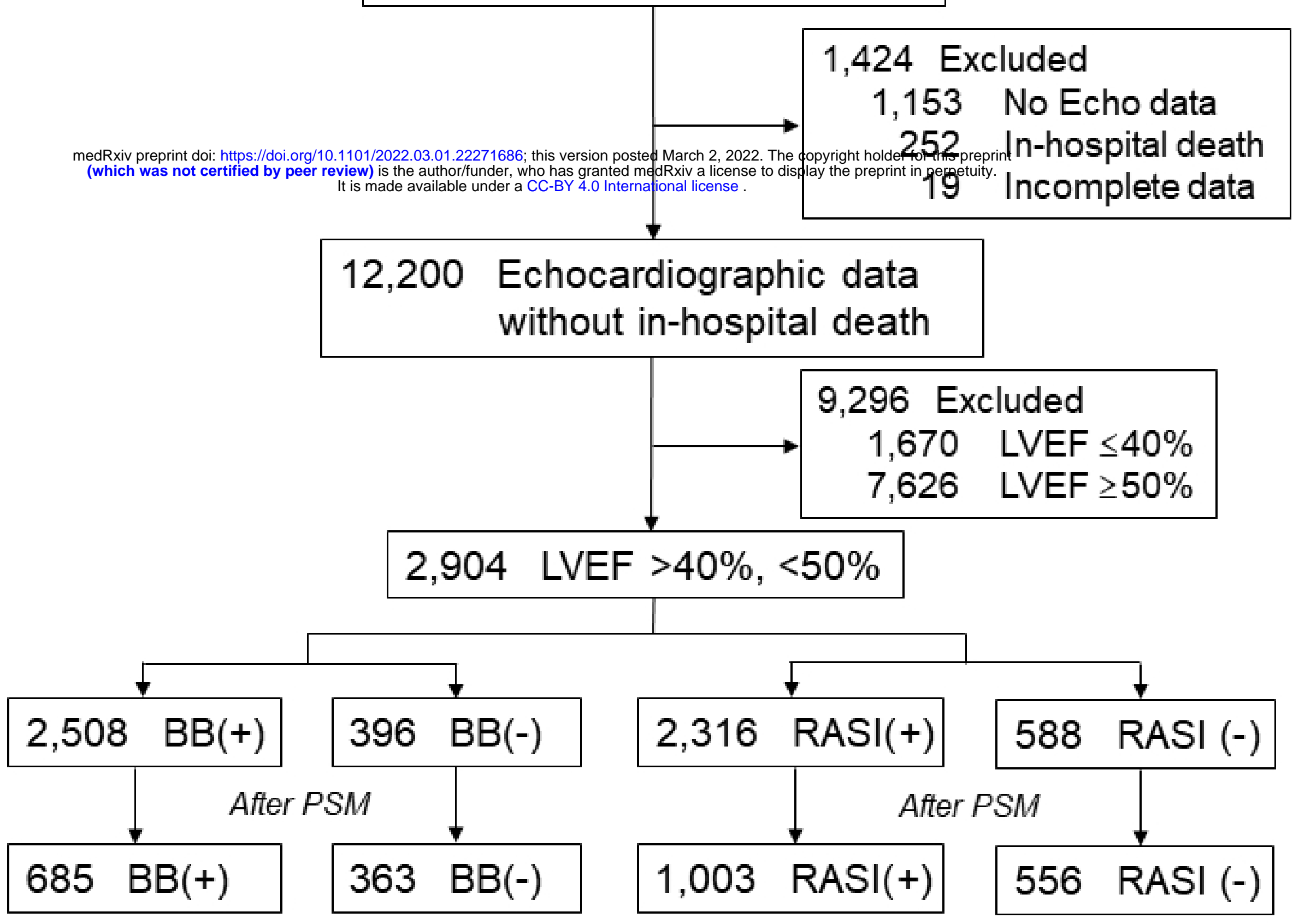


A

MACE

B

Myocardial infarction

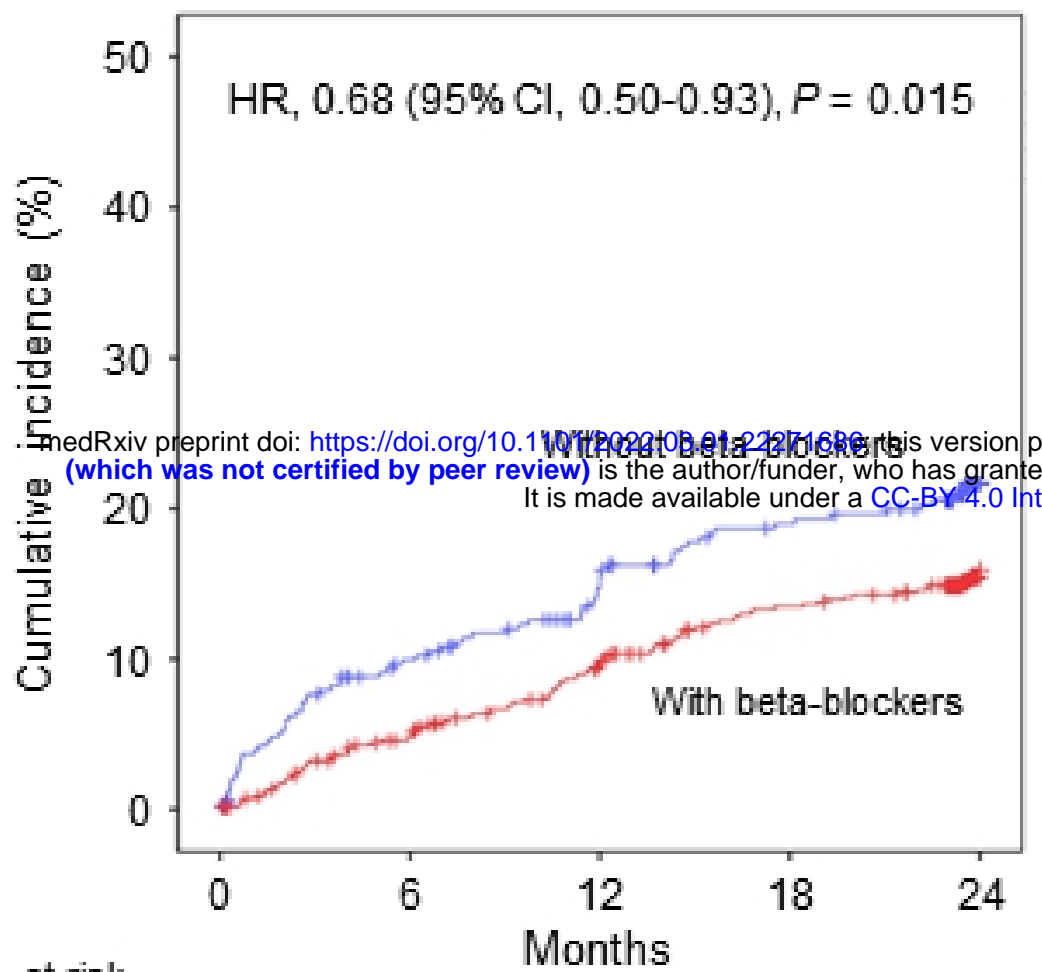

No. at risk

Months

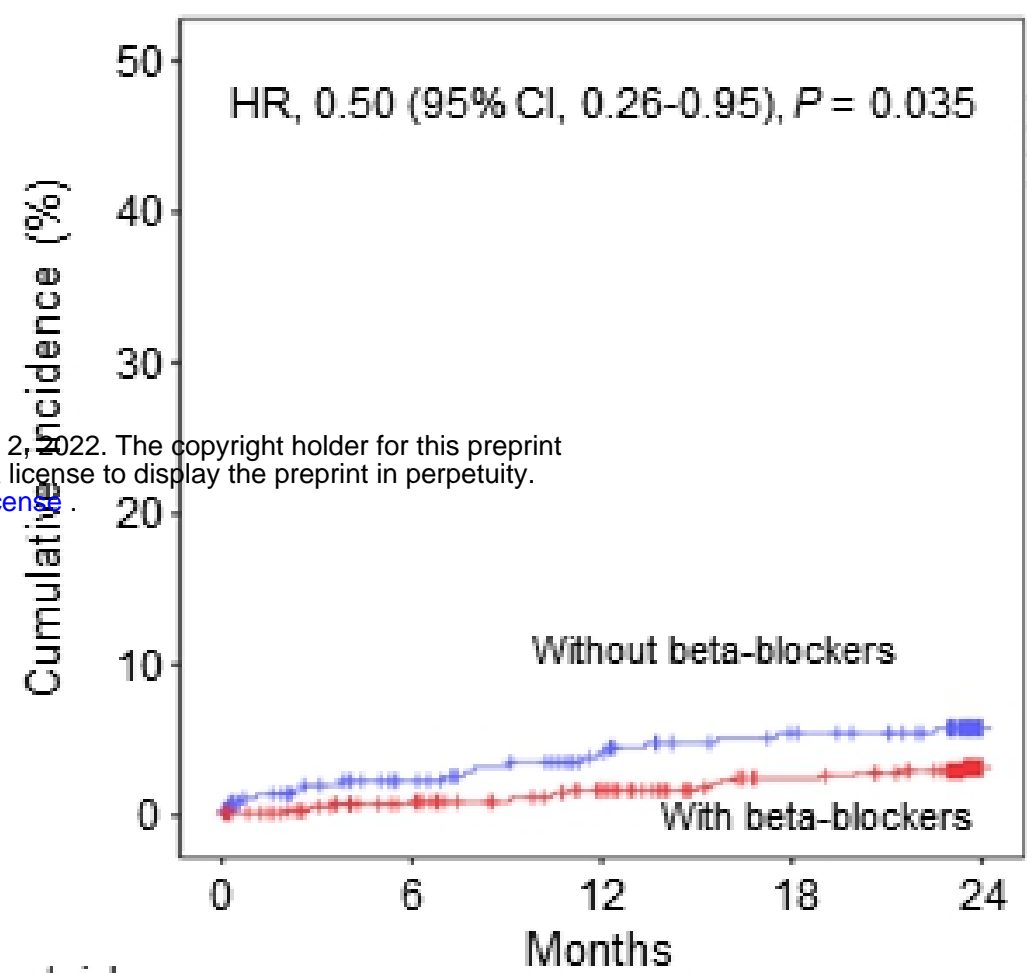

$\begin{array}{llllll}\text { BB (+) } & 685 & 635 & 588 & 551 & 397 \\ \text { BB (-) } & 363 & 310 & 281 & 261 & 182\end{array}$

No. at risk

$\begin{array}{llllll}\text { BB (+) } & 685 & 654 & 626 & 595 & 436 \\ \text { BB (-) } & 363 & 323 & 302 & 287 & 199\end{array}$

C

Revascularization

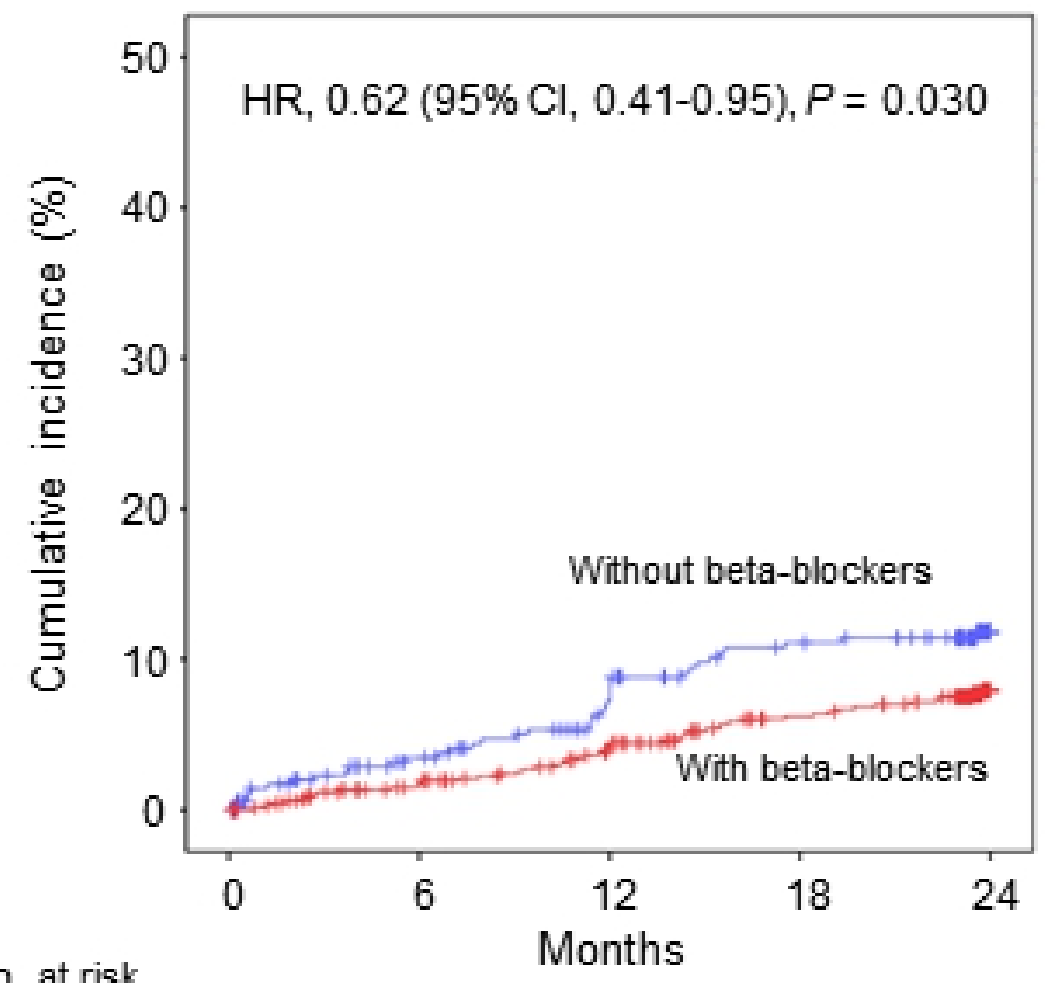

No. at risk

$\begin{array}{llllll}\text { BB (+) } & 685 & 648 & 609 & 573 & 415 \\ \text { BB (-) } & 363 & 319 & 291 & 270 & 189\end{array}$

D

Cardiac death

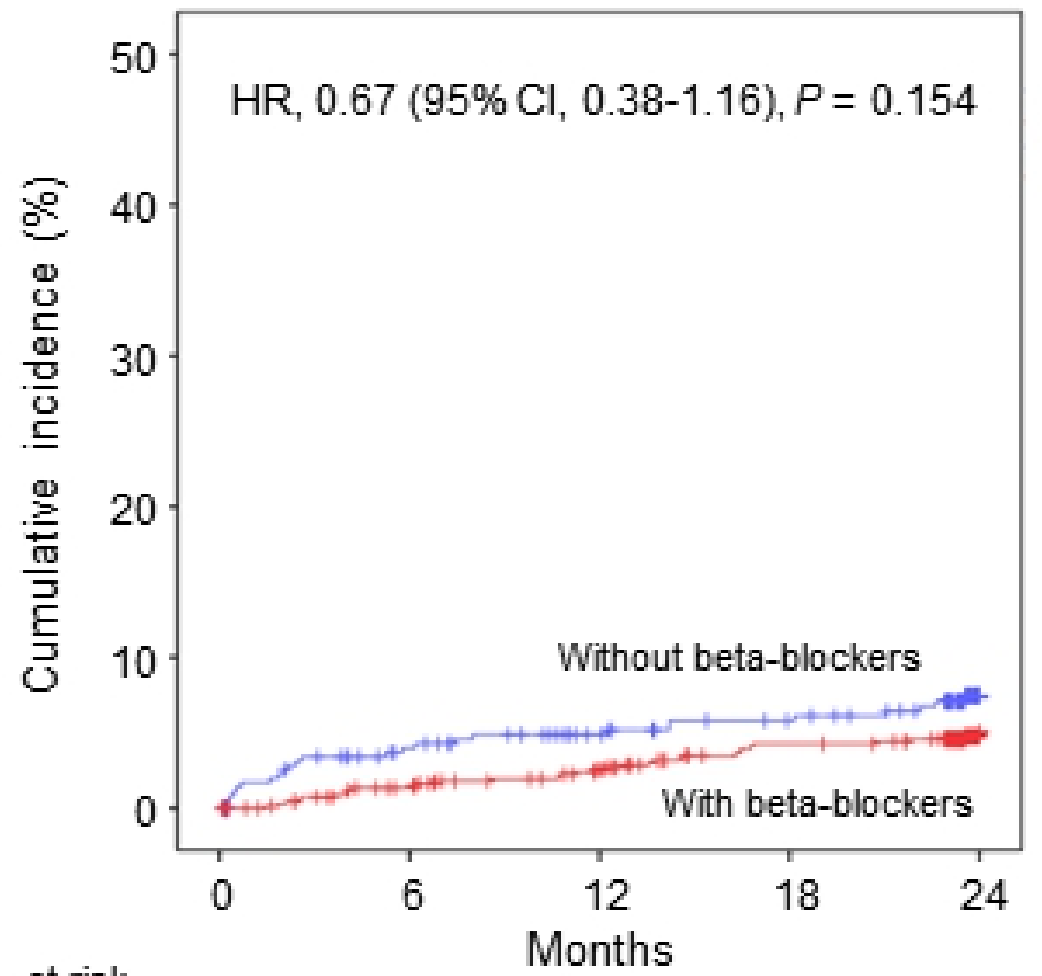

No. at risk

$\begin{array}{llllll}\text { BB (+) } & 685 & 659 & 635 & 608 & 446 \\ \text { BB (-) } & 363 & 329 & 312 & 302 & 207\end{array}$




$\begin{array}{cc}\text { With } & \text { Without } \\ \text { beta-blocker } & \text { beta-blocker } \\ (\mathrm{N}=685) & (\mathrm{N}=363) \\ \text { No. of patients with events } \\ \text { (Rate per } 100 \text { patient-years) }\end{array}$

Hazard Ratio $(95 \% \mathrm{Cl})$

$P$ for interaction

Age (years)

$\begin{array}{lcc}<65 & 30(5.9) & 18(7.3) \\ \geq 65,<80 & 55(10.3) & 36(15.6) \\ \geq 80 & 18(13.0) & 19(20.4)\end{array}$

$18(13.0) \quad 19(20.4)$

medRxiv preprint doi: https://doi.org/10.1101/2022.03.01.22271686; this version posted March 2, 2022. The copyright holder for this preprint Which was not certified by peer review) is the author/funder, who has granted medRxiv a license to display the preprint in perpetuity.

$\begin{array}{lcc}\text { Male } & 61(7.2) & 42(10.1) \\ \text { Female } & 42(12.6) & 31(20.1) \\ \text { Hypertension } & & \\ \text { Yes } & 66(12.3) & 50(19.6) \\ \text { No } & 37(5.7) & 23(7.3)\end{array}$

Diabetes mellitus

$\begin{array}{lll}\text { Yes } & 39(12.8) & 23(16.3) \\ \text { No } & 64(7.3) & 50(11.6)\end{array}$

Prior myocardial infarction

$\begin{array}{lcc}\text { Yes } & 18(18.6) & 6(13.9) \\ \text { No } & 85(7.8) & 67(12.7)\end{array}$

Current smoker

$\begin{array}{lcc}\text { Yes } & 31(6.6) & 24(11.2) \\ \text { No } & 72(10.1) & 49(13.7)\end{array}$

Killip class

$\begin{array}{lcc}1 & 70(7.7) & 42(9.5) \\ \geq 2 & 33(12.2) & 31(23.7) \\ \text { eGFR } & \left(\mathrm{mL} / \mathrm{min} / 1.73 \mathrm{~m}^{2}\right) & \\ \geq 60 & 63(6.6) & 46(9.9) \\ <60 & 40(17.9) & 27(25.3)\end{array}$

Left ventricular ejection fraction (\%)

$$
\begin{array}{lll}
>40, \leq 45 & 44(8.5) & 36(13.4) \\
>45,<50 & 59(8.9) & 37(12.2)
\end{array}
$$

Type of myocardial infarction

$\begin{array}{lcc}\text { STEMI } & 45(7.2) & 38(12.6) \\ \text { NSTEMI } & 58(10.4) & 35(12.9)\end{array}$

Inhibitors of renin-angiotensin system

$\begin{array}{ccc}\text { Yes } & 58(8.0) & 44(13.5) \\ \text { No } & 45(9.9) & 29(11.8) \\ \text { All } & 103(8.7) & 73(12.8)\end{array}$

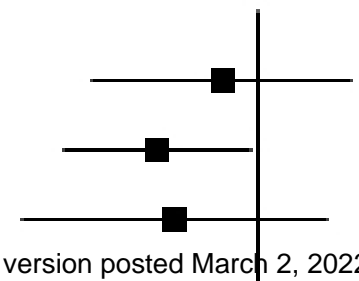

$0.85(0.46-1.57)$

0.664

$0.63(0.40-0.97)$

$0.68(0.33-1.41)$

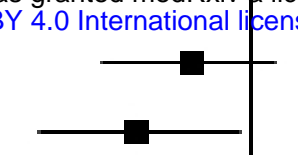

$0.76(0.50-1.13)$

0.412

$0.59(0.37-0.96)$

$0.64(0.44-0.93)$

0.769

$0.80(0.47-1.36)$

$0.80(0.46-1.41)$

0.558

$0.65(0.45-0.94)$

$1.13(0.32-4.06)$

0.187

$0.62(0.44-0.85)$

$0.46(0.26-0.82)$

0.323

$0.75(0.51-1.08)$

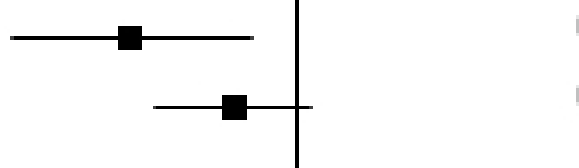

$0.86(0.58-1.27)$

0.066

$0.47(0.28-0.80)$

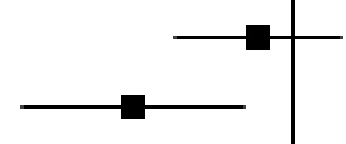

$0.64(0.44-0.94)$

0.741

$0.75(0.44-1.29)$

$0.64(0.41-1.00)$

0.354

$0.71(0.46-1.08)$

$0.56(0.36-0.88)$

0.316

$0.76(0.50-1.17)$

$0.62(0.41-0.92)$

0.533
$0.68(0.50-0.93)$

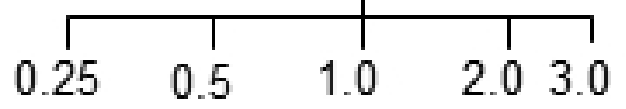

Beta-blockers better No beta-blockers better

Figure 3 


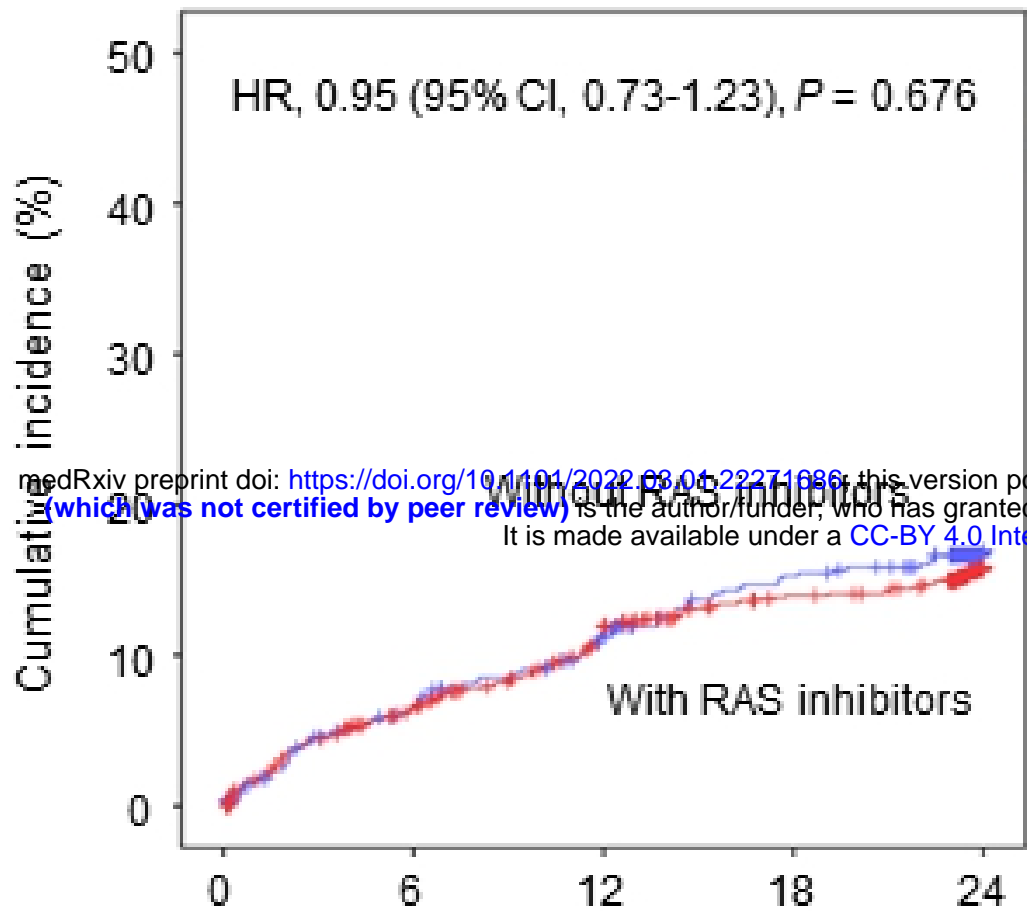

No. at risk

$\begin{array}{lccccc}\text { RASI (+) } & 1003 & 911 & 838 & 789 & 565 \\ \text { RASI (-) } & 556 & 500 & 463 & 430 & 309\end{array}$

C

Myocardial infarction

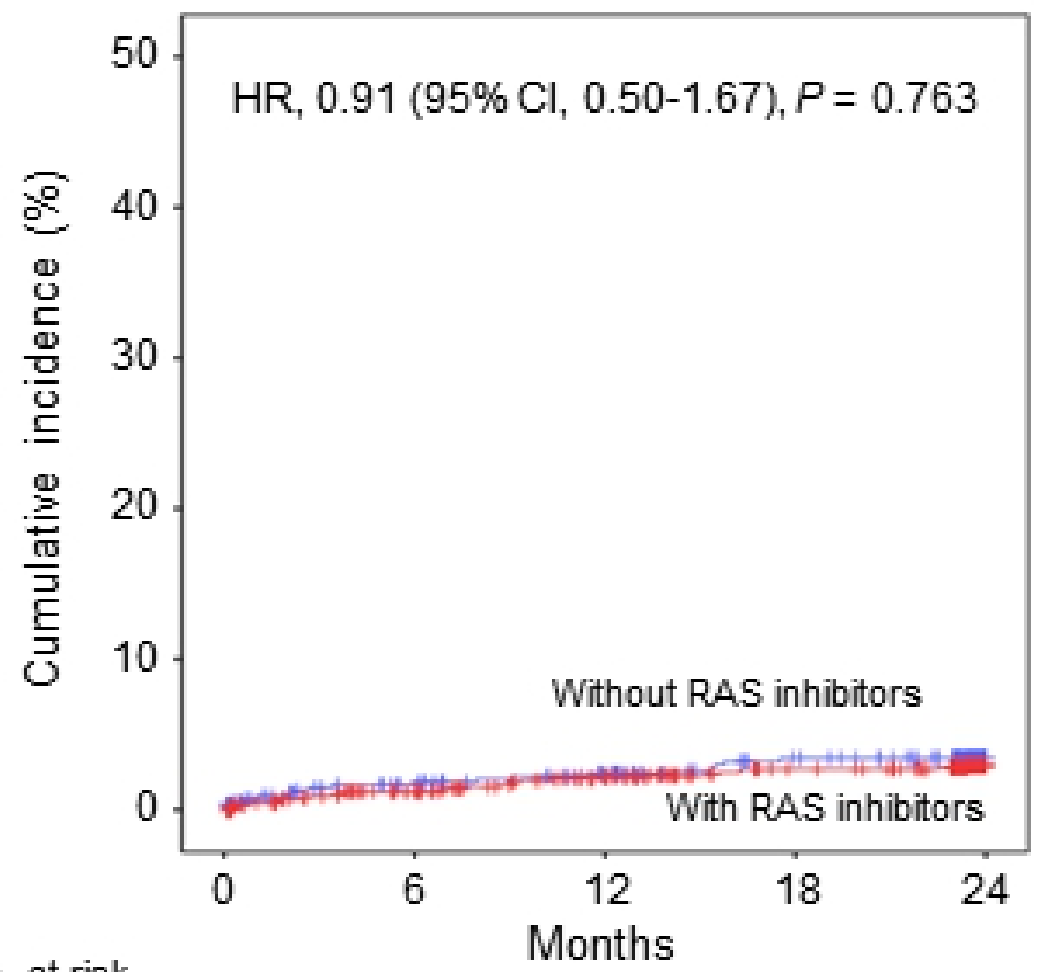

No. at risk

$\begin{array}{llllll}\text { RASI (+) } & 1003 & 945 & 901 & 861 & 620\end{array}$

$\begin{array}{llllll}\text { RASI (-) } & 556 & 516 & 496 & 469 & 338\end{array}$

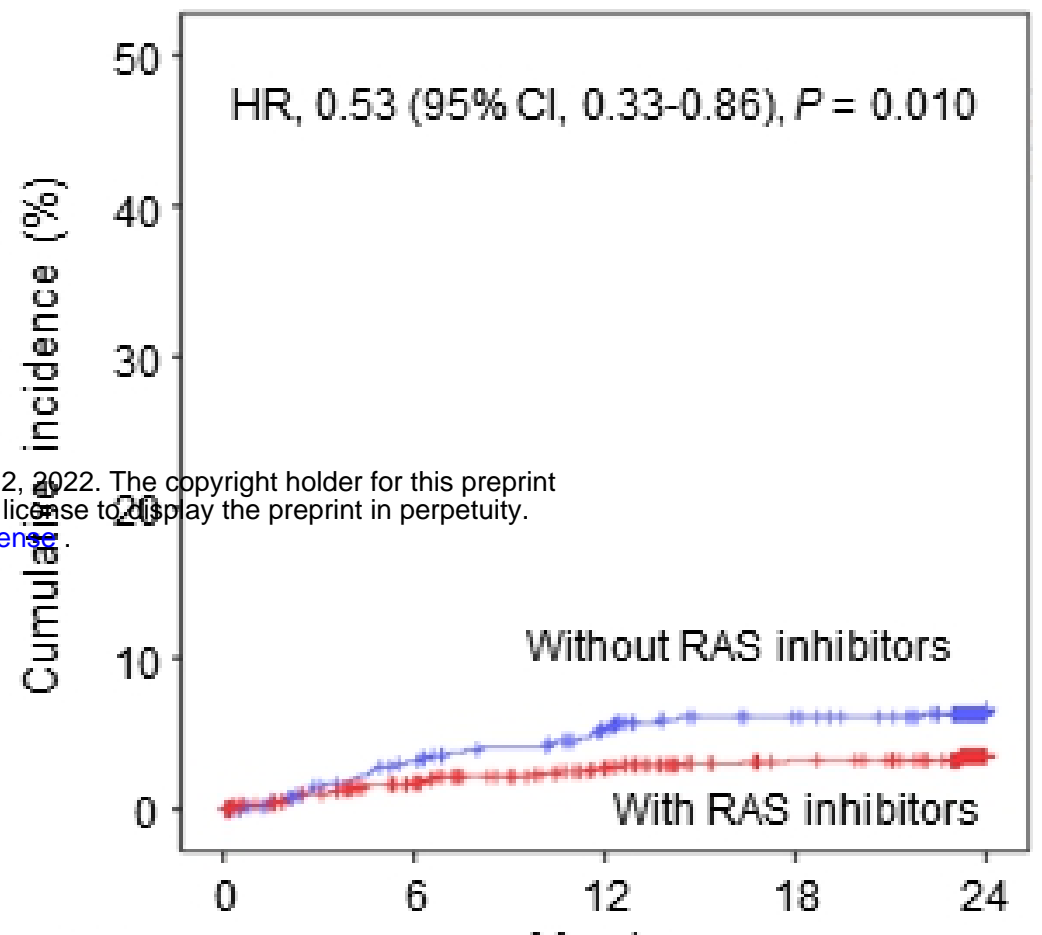

No. at risk

Months

$\begin{array}{lccccc}\text { RASI (+) } & 1003 & 940 & 895 & 857 & 616 \\ \text { RASI (-) } & 556 & 511 & 483 & 460 & 329\end{array}$

D

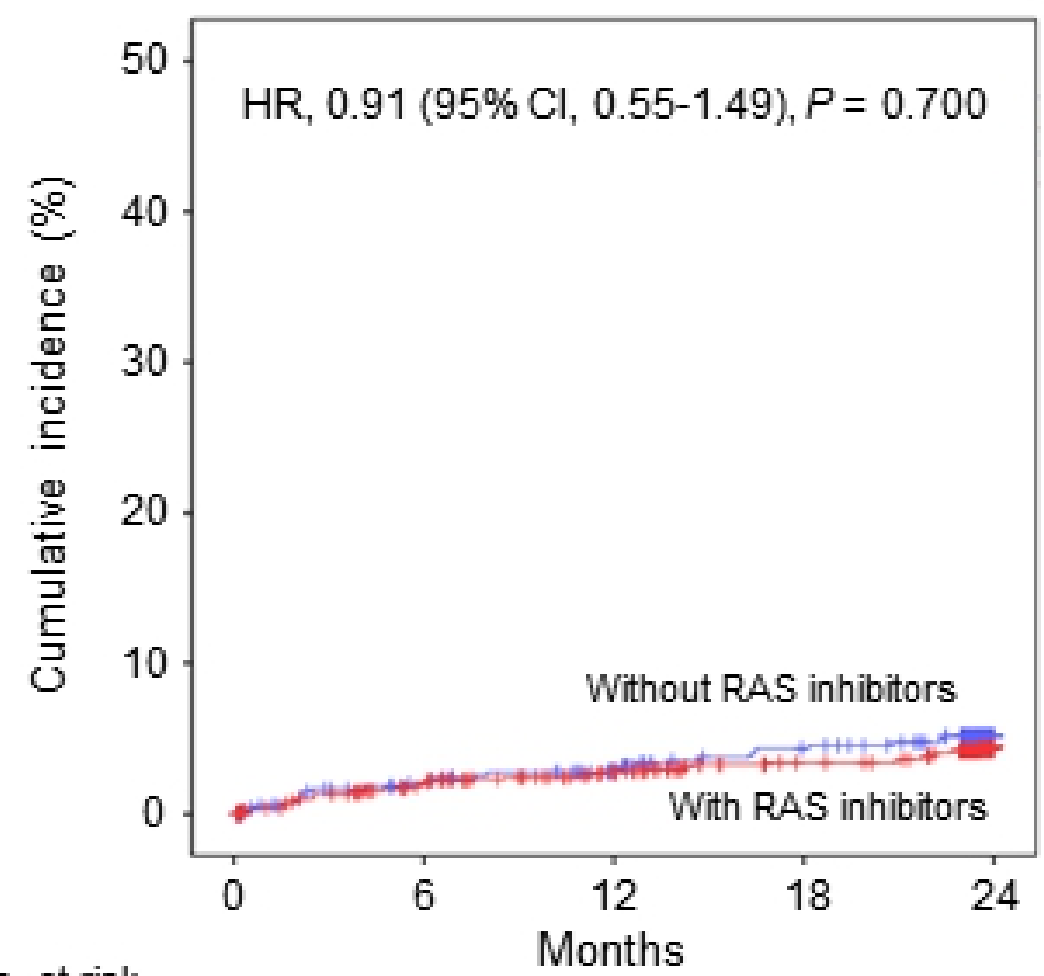

No. at risk

$\begin{array}{lccccc}\text { RASI (+) } & 1003 & 953 & 917 & 882 & 632 \\ \text { RASI (-) } & 556 & 524 & 505 & 482 & 346\end{array}$




\section{With Without RAS \\ RAS inhibitors inhibitors \\ $(\mathrm{N}=994) \quad(\mathrm{N}=556)$ \\ No. of patients with events}

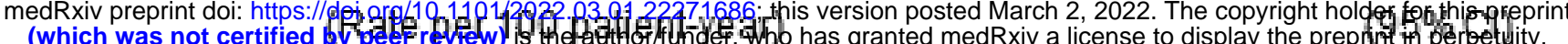
It is made available under a CC-BY 4.0 International license

All

$33(1.8)$

$34(3.5)$

ACEI $(N=650)$

20 (1.7)

ARB ( $N=344)$

$13(2.2)$
Hazard Ratio

$0.53(0.33-0.86)$

$0.56(0.32-0.996) \quad 0.653$

$0.49(0.26-0.94)$

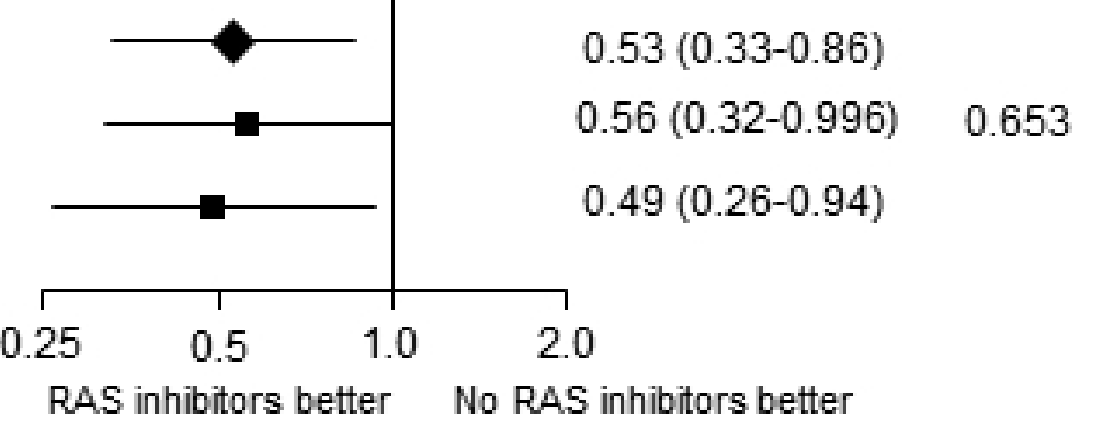

RAS inhibitors better No RAS inhibitors better

$P$ for interaction 